\title{
Solovyanenko N.I.
}

Institute of State and Law RAS, Business and Corporate Law Department, Senior Research Fellow, Candidate of Legal Sciences

\section{CROSS-BORDER BUSINESS OPERATIONS IN DIGITAL ECOSYSTEMS OF THE EAEU: LEGAL ISSUES}

\begin{abstract}
Cross-border business operations in the digital ecosystems of the EAEU are carried out using electronic document management and the legal structure of the cross-border space of trust. Within the framework of the cross-border trust space, the legal structure of a trusted third party is used, which identifies participants in the electronic document flow; signs an electronic document with an electronic signature and verifies it; registers the date and time of sending and receiving an electronic document; and stores electronic documents. Special legal constructions are used to ensure the reliability of electronic document management.
\end{abstract}

Аннотация

Трансграничные бизнес-операџии в циифровых экосистемах ЕАЭС осуществляются с применением электронного документооборота и юридической конструкции трансграничного пространства доверия. В рамках трансграничного пространства доверия применяется правовая конструкиия доверенной третьей стороны, которая осуществляет идентификацию участников электронного документооборота; подписание электронного документа электронной подписью и ее проверку; регистрацию дать и времени отправки и получения электронного документа; хранение электронных документов. Используются особые юридические конструкции в целях обеспечения надежности электронного документооборота.

Key words: legal significance of electronic documents, legal structure of cross-border environment of trust, digital ecosystems, electronic signature, trust services, trusted time stamp.

Ключевые слова: юридическая значимость электронных документов, правовая конструкция трансграничного пространства доверия, цифровые экосистемы, электронная подпись, доверенные сервисы, метка доверенного времени.

The latest conditions for access of economic entities to foreign markets, as well as the implementation of cross-border business operations, include such an essential component as the ability to implement in digital ecosystems. The normative legal basis for the creation and functioning of digital ecosystems in the EAEU is the Treaty on the Eurasian economic Union of may 29, 2014 (including the Protocol on information and communication technologies and information interaction within the EAEU (Annex No. 3 to the Treaty on the EAEU); The main directions of implementation of the digital agenda of the Eurasian economic Union until 2025, approved by The decision of the Supreme Eurasian economic Council of October 11, 2017 N 12.

In the regulatory legal acts of the EAEU, the digital ecosystem is defined as "an open sustainable system that includes entities: individuals, legal entities, virtual entities, as well as communications and relationships of these entities in digital form based on digital platform services" [4, p.230-235].

Electronic legal interaction and the use of digital services in the field of civil turnover simplifies cross-border business operations, increases the efficiency and transparency of international commercial transactions, while promoting stricter compliance with regulatory requirements, especially in the cross-border exchange of data and documents in electronic form. "In the branches of law, digitalization acquires its own specific features that characterize the digital space and information infrastructure that is being formed in the legal field" [2,p.916-920]. The legal task of digital ecosystems is to create a legal environment in which management and 
technological solutions are adequately translated into the language of legal categories, which in turn is associated with ensuring the legal significance of electronic documents and creating a legal model of the "digital space of trust".

Various digital ecosystems are currently being developed in the Eurasian economic Union. Decision of the Board Eurasian economic Commission of August 6, 2019 N 135 approved technical specification for the provision of services for the development and implementation of the Eurasian network of industrial cooperation, subcontracting and technology transfer focused on creating the conditions for digital transformation of industrial cooperation within the EEU and the digital transformation of industry in the member States of the Union. Regulatory documents of the EAEU provide for the integration of the Eurasian network with promising projects of the digital agenda of the Union (digital traceability of goods, the use of electronic accompanying documents, digital transport corridors, regulation of data turnover, and others). The Eurasian network is an automated system designed, among other things, to stimulate innovation processes through technology transfer and the possibility of promoting the products of economic entities using international digital ecosystems of member States and third countries. The technical specification for the development and implementation of the Eurasian network provides, in particular, such components as technology transfer services for the formation of technological requests and technological proposals; legally significant document flow, data exchange between economic entities( EDI); a service for presenting the possibility of concluding smart contracts and a number of others.

By order of the Eurasian intergovernmental Council No. 4 of January 31, 2020 "on the formation of the ecosystem of digital transport corridors of the Eurasian economic Union", the action plan for the formation of the ecosystem of digital transport corridors of the EAEU was approved. The ecosystem of digital transport corridors is an open digital environment for the exchange of logistics information, which includes a large number of digital platforms and information systems, the owners and / or operators of which can be both business and public authorities. The ecosystem integrates information about vehicles, crews, cargo, permits and accompanying documents at all stages of transportation, technological operations. The project aims to solve such legal problems as a complete transition to electronic data exchange, excluding paper document flow as support for transport and logistics operations; creation of unified standards for transport and logistics services; transition to an end-to-end integrated surveillance system based on data analysis and freeing carriers from a significant share of administrative burden.

The creation, implementation and maintenance of the ecosystem provides for the interaction of digital platforms of the member States with each other directly or through the integrated information system of the Union. The integrated information system of the EAEU is designed to ensure the interstate exchange of data and electronic documents within the Union, with nonmember States (third countries), international organizations and integration associations, the creation of common information resources for member States, the implementation of common processes within the Union, as well as ensuring the activities of the Union's bodies (Decision of the Board of the Eurasian economic Commission No. 55 of April 2, 2019 ).

Cross-border cooperation in the legal and technical fields is associated with the formation of a cross-border space of trust. The use of reliable, trustworthy legal instruments has become an essential requirement in the e-economy due to the increasing importance and confidentiality of online transactions. As legal scholars rightly point out, " in such a system of economic behavior, there are many specific risks, opportunities, loopholes for illegal behavior, challenges for the state in terms of regulatory opportunities. The main problem, of course, is trust. Formally, all participants of new relations are interested in it " [1, p. 39-47].

For example, it is important that the parties identify themselves when they begin to make transactions online, "since it is necessary to form a certain level of trust in the authenticity of the interacting parties" [3.]. the Conclusion of a transaction in electronic form may also require the identification of the parties in order to be sure that they Express their consent to the content of the 
transaction. In addition, it is necessary to ensure the integrity of the document, as well as to indicate in the document a specific date and time of its signing. Finally, in some cases, it is necessary that documents are sent by one party to the other party through secure channels to ensure that the time of sending and receiving the document can be recorded. Many transactions conducted over the Internet require verification of the identity of the website owner in order to be sure that the website is owned by a legal entity and is actually operated by that entity.

Goals, objectives, and elements of cross-border space of trust in the EEU is determined by the "Strategy for the development of transboundary space of trust", approved by Decision of Board of the Euroasian economic Commission from September 27, 2016 N 105, and "Concept use in international information exchange mechanisms and binding electronic documents", approved by Decision of the Board Eurasian economic Commission of 18 September 2014 N 73.A crossborder trust space is "a set of legal, organizational and technical conditions agreed upon by member States in order to ensure trust in the inter-state exchange of data and electronic documents". The concept of a cross-border space of trust is enshrined in the Protocol on information and communication technologies and information interaction within the EAEU (Annex No. 3 to the Treaty on the EAEU). The Protocol contains such basic legal components of the trust space as: an electronic document, a trusted third party, a common infrastructure for documenting information in electronic form; subjects of electronic interaction. The General legal outline of electronic document management in the space of trust is that the legal force of electronic documents exchanged by subjects of electronic interaction using various mechanisms for protecting electronic documents is ensured by using services provided by operators of the infrastructure for electronic documentation of information, including services of a trusted third party.

In accordance with paragraph 20 of the Protocol, the operators of the services of a trusted third party are the Eurasian economic Commission and the authorized bodies of the member States or certain organizations (accredited) by them. Trusted third parties, which are elements of the national trust spaces of the member States or elements of the cross-border trust space, can perform the following technological and legal functions:

- identification and authentication of participants in the electronic document flow;

- exchange of electronic documents between participants of electronic business operations;

- storage of electronic documents, including electronic signature, signing of electronic document with electronic signature and verification of electronic signature;

- registration of the date and time of legal actions;

- verification of the authority of the participant of electronic document management to sign and (or) transfer electronic documents;

- verification of the authenticity of electronic documents after a certain period of time;

- provision of electronic evidence of legal actions performed by participants in the electronic document flow, and others.

Electronic document management in a cross-border space of trust is carried out on the basis of the fundamental legal principles formulated by UNCITRAL that underlie interaction in the digital business environment.

The principle of party autonomy. The use of the provided funds should be optional.The parties should retain freedom of choice when deciding on the applicable level of security. Legal norms are considered as "legal tools" made available to market participants.

The principle of neutrality of both the technological and economic models. The creation of a legal framework should not hinder the development of innovation and entrepreneurial opportunities by establishing strict rules that encourage the introduction of some technical solutions or economic models to the detriment of others.

The principle of non-discrimination. The legal validity and applicability of electronic identification or a trust service as evidence in legal proceedings should not be rejected solely on the grounds that they are carried out in electronic form. 
The principle of functional equivalence. Providing comparable legal functions regardless of whether the actions are performed in a physical or electronic environment.

The trust space unites many independent participants who interact with each other to carry out complex electronic operations (legal actions) in compliance with the established degree of reliability. In this regard, they establish legal requirements that go beyond ensuring the sole operability of the electronic document management system, but provide for additional measures to ensure the confidence of participants as a result of operations with electronic documents and the willingness to rely on them. Such measures are provided for in the EAEU regulatory document "Requirements for the creation, development and functioning of a cross-border trust space", approved by the decision of the EEC Council No. 96 of December 5, 2018. In international practice, various definitions of confidence levels developed by public and private structures are used. Their formulations are regularly updated to reflect the development of technology. In the light of the applied principle of technological neutrality, only confidence levels with technologically neutral definitions are taken into account. The European regulation (eidas regulation) defines three levels of confidence (reliability) associated with the identification of a participant in electronic interaction: low, significant and high, and also specifies the criteria associated with them. Thus, a" low " level of reliability corresponds to a low degree of confidence in the identity of the person claimed or attributed to him / herself; a" significant "level of reliability corresponds to a significant degree of confidence in the identity claimed or attributed to a given person, and at a" high "level of reliability, the degree of confidence in the identity claimed or attributed to a given person is even higher than at a"significant" level. Minimum technical

specifications and procedures have also been established to determine the reliability and quality of recording processes, the management of electronic identification and authentication tools, and the organization and management of cross-border trust service providers.

\section{Литература}

1. Габов А.В Изменения в праве как следствие развития цифровой экономики//Пермский юридический альманах. 2020. № 3. С. 39-47.

2. Лебедь К.А. Свойства электронного судебного решения// Инновации. Наука.

Образование. 2020. № 21. С. 916-920

3. Сабанов А.Г. Уровни доверия к результатам идентификации и аутентификации в период цифровой трансформации //Вопросы кибербезопасности. 2019. № 5(33)

4. Шпинев Ю.С. Искусственный интеллект - вопросы правового регулирования. В книге: Право и бизнес: правовое пространство для развития бизнеса в России. Коллективная монография. В 4-х томах. Отв. редактор С.Д. Могилевский [и др.]. - М. - 2020. - С. 230235. 